IJTAR

International Journal of Transactional Analysis Research
$4(1), 80-80$

https://doi.org/10.29044/v4i1p80

\title{
The mutually beneficial process of research and practical work.
}

(C) 2012 Roland Johnsson

The focus of this workshop will be on the cons and pros of doing research on your own clinical practice.

The workshop will be based on my work with my PhD dissertation titled Transactional Analysis Psychotherapy - Three Methods Describing a Transactional Analysis Group Therapy. This is described in some detail in the paper produced to accompany my Keynote Speech, and included at the start of this Proceedings document, so I will not repeat that content here.

My PhD work (2011) was first developed through many years of TA training and practical work as TA psychotherapist. Then after 15 years it was tested in research work. I want to show that there is a mutually beneficial process between the researcher and the practitioner.

From my dissertation I will invite people to use some of my research classifications, like the CCRT by Luborsky (or the Ohlsson, Björk and Johnsson (1992) script checklist or my revised version of McNeel's (1975) 42 sub-categories (components) as tools for deepening their understanding and efficiency as clinicians. From a researcher point of view I will invite the practitioners to be 'local clinical scientists' (Stricker \& Trierweller, 1995; Stricker, 2002) and use a scientific attitude in their work.

Possible outcome of the workshop experiences and discussions will be to:

- Stimulate practitioners to do research

- Understand the practical use of research
- Understand the meaning and benefits of different types of research

- Understand the practitioner's problems and difficulties with research.

\section{References}

Johnsson, R. (2011). Transactional Analysis Psychotherapy - Three Methods Describing a Transactional Analysis Group Therapy, Department of Psychology, Lund University, ISBN 978-91-7473-185-9

Luborsky L, \& Crits-Christoph P. (1998). Understanding Transference: The CORE Conflictual Relationship Theme Method, (2nd ed.) Washington, DC, American Psychological Association.

McNeel, J. R. (1975). A study of the effects of an intensive weekend group workshop. Ph.D. dissertation, California School of Professional Psychology.

Ohlsson, T., Björk, A. \& Johnsson, R. (1992). Transaktionsanalytisk psykoterapi - TA i teori och praktik. (Transactional Analysis Psychotherapy - TA in Theory and Practice) Lund: Studentlitteratur.

Stricker, G. (2002) What is a scientist-practitioner anyway? Journal of Clinical Psychology 58, 1277-1283

Stricker, G. \& Trierweller JS (1995) The local clinical scientist. A bridge between science and practice. The American Psychologist 50, 995-1002. 